\title{
AKTIVITAS DAKWAH DAN KEPAHLAWANAN TUANKU TAMBUSAI
}

\author{
Ginda \\ Dosen Jurusan Ilmu Komunikasi, Fakultas Dakwah dan Komunikasi,UIN Suska Riau, \\ Jl. HR Soebrantas Km 15 Simpangbaru, Tampan, Pekanbaru 50275
}

\begin{abstract}
Abstrak
Tuanku Tambusai seorang anak negeri Riau telah ditetapkan sebagai pahlawan nasional karena jasa dan perjuangan yang dilakukan melawan kolonial Belanda. Sebagai pahlawan Nasional, sisi heroiknya melawan Belanda telah banyak mendapat perhatian, namun sisi keagamaandan dakwah sangat sedikit yang dikaji, sementara motif perlawanan dan perjuangannya terhadap Belanda tidak terlepas dari perspektif dan keulamaan beliau yang memandang Belanda adalah penguasa-penguasa zalim yang harus di tumpas. Dakwah dan perjuangan mengusir Belanda merupakan dua " sisi mata uang” dalam kepribadian Tuanku Tambusai. Semangat Dakwah dan perjuangan melawan Belanda telah membanya sebagai tokoh yang memberikan kontriubusi yang signifikan dalam penyebaran Islam di daerah, Sumatera Barat, Sumatera Utara dan Propinsi Riau.
\end{abstract}

Kata kunci: Tuanku Tambusai, Aktivitas dakwah dan Kepahlawanan

\section{Pendahuluan}

Menegakkan sebuah tatanan masyarakat yang mulia, elegan, adil, berwibawa dan bertahan di muka bumi adalah tujuan utama al-Qur'an. Al-Qur'an menghendaki sebuah tatanan masyarakat yang etis, terbuka (transparan), egalitarian, jujur dan adil. Dalam konteks kemanusiaan masyarakat dibentuk membentuk dengan sendirinya - dengan tujuan saling menguatkan, saling menolong, dan saling menyempurnakan.

Tujuan utama al-Qur'an yang seperti ini telah menjadi motivasi penting bagi ummat Islam, untuk mengembangkan Islam ke seluruh penjuru dunia dalam berbagai dimensi, baik waktu, tempat, kondisi maupun situasi.

Dalam proses Islamisasi Nusantara, secara faktual telah ditemukan bahwa dakwah memegang peranan sangat penting. Meskipun terdapat perdebatan dan diskusi yang panjang mengenai kedatangan Islam ke Nusantara ini, tapi telah disepakati oleh para sejarawan Islam bahwa proses Islamisasi dan perkembangan Islam melalui dakwah dan pendidikan oleh muballig -muballigh Islam selanjutnya setelah Islam sampai di Nusantara dilakukan oleh orang -orang Islam sendiri. Hal ini sesuai dengan salah satu kesimpulan seminar tentang masuknya Islam Ke Indonesia yang dilakukan di Medan pada tahun 1963 bahwa, setelah Islam sampai di Indonesia proses peng-Islaman selanjutnya orang-orang Indonesia ikut aktif ambil bagian.(A. Hasjmy, 1989:7)

Secara historis fakta seperti ini tentu tidak sulit dipahami, karena dakwah Islam menjadi instrument penting dalam proses perkembangan Islam dan transmissi gagasan pembaharuan bahkan jauh sebelum bangsa Eropa termasuk -Belanda- datang dengan konsep kolonialismenya. Dalam ungkapannya Rasi'in menjelaskan bahwa, pendidikan Islam dan dakwah berjalan berkembang seiring dengan dakwah dan penyebaran Islam itu sendiri, baik dikalangan masyarakat, maupun istana raja-raja. Dakwah dan Pendidikan Islam pada saat itu mengambil bentuk antara lain khalaqoh, dan tatap muka perorangan di mesjid atau mushalla maupun di pesantrenpesantren.(Abuddin Nata, 2003:14).

Urgensi dakwah dalam proses Islamisasi dan pembaruan Islam di Nusantara, tentu tidak lepas dari kreativitas muballigh dan tokoh-tokoh Islam yang turut mengambil peran penting dalam proses Islamisasi dan perkembangan Islam, mereka ini tersebar diseluruh pelosok Nusantara. Tidak berbeda halnya dengan apa yang terjadi dengan proses Islamisasi dan perkembangan Islam di Nusantara pada umumnya, daerah Rokan hulu yang pada abad ke 19 masih merupakan bagian 
dari sumatera tengah dan kemudian masuk dalam wilayah administrative Propinsi Riau yang di undangkan dengan Undang-undang N0 61 tahun 1958. Sebagaimana halnya daerah lain, Islam masuk ke daerah Rokan tidak dapat dipastikan, yang dapat diprediksi adalah, daerah Rokan pertama kali bersentuhan dengan Islam diperkirakan ketika kerajaan-kerajaan Islam sudah mulai teratur. Islam diketahui telah ada di daerah Rokan sekitar abad ke XIV dan ke XV. Perkembangan selanjutnya tidak diperoleh data lagi, hingga munculnya Kerajaan Tambusai dan telah diperintah oleh Rajanya yang ke XIV yakni Sri Sulthan Ibrahim pada tahun 1819 M.(Umar Ahmad Tambusai,1978:24). Pada masa ini agama Islam telah berkembang pesat disepanjang Sungai Rokan, yang disiarkan oleh muballigh-muballigh Islam yang diperkirakan datang dari Aceh.

Perkembangan Islam di daerah Rokan ini, faktor dakwah Islam sebagai instrument yang digunakan oleh muballigh-muballigh Islam tentu tidak dapat di abaikan. Kontinuitas perkembangan Islam dilakukan oleh tokohtokoh Islam setempat, sebagaimana yang telah terjadi di seluruh pelosok Nusantara pada waktu itu.

Salah seorang tokoh penting yang turut memberikan kontribusi dalam Islamisasi dan perkembangan Islam dengan dakwah di Daerah Rokan, hususnya Rokan Hulu abad ke 19, adalah Muhammad Saleh yang dikenal dengan Tuanku Tambusai. Sebagai seorang tokoh dan Pahlawan Nasional, yang ditetapkan dengan SK. Presiden Republik Indonesia, N0.071/TK/Tahun 1995, tgl. 7 Agustus 1995. perjuangan Tuanku Tambusai menentang kolonialisme telah banyak dikaji dan diteliti oleh berbagai pihak, dan telah melahirkan berbagai kesimpulan tentang profil Tuanku Tambusai hususnya dalam perspektif dan sisi kepahlawanan. Akan tetapi perjuangannya dalam proses pengembangan Islam amat sedikit yang diteliti, dan dikaji. Sementara dalam beberapa literatur ditemukan Tuanku Tambusai adalah salah seorang dari Kelompok Ulama Paderi yang jelas-jelas sangat konsern dengan perkembangan Islam dan perjuangan melawan kolonialisme. Sulit untuk dipungkiri secara logis, bahwa sebagai seorang ulama Paderi, Tuanku Tambusai memiliki peran dan kontribusi penting dalam pengmbangan Islam di Rokan Hulu dan sekitarnya, bersamaan dengan kegiatan perjuangannya melawan kolonial Belanda.

Jurnal ini diangkat dan diresume dari hasil penelitian yang dilakukan oleh penulis sendiri tentang kegiatan dakwah dan pembaharuan Islam yang dilakukan oleh Tuanku Tambusai. Penelitian yang dilakukan untuk menemukan sisi perjuangan beliau dalam aspek pengembangan dan pembaharuan Islam, sesungguhnya banyak hal yang perlu di gali dan dijelaskan dan perlu diketahui dari biografi beliau yang terkait dengan usaha dan kontribusinya dalam proses pengembangan Islam di daerah Rokan hulu dan sekitarnya pada abad ke 19. Hasil kajian ini akan melengkapi potongan-potongan riwayat hidupanya yang tentu sangat berharga bagi pengembangan ilmu pengetahuan bagi bangsa ini di masa depan, sehingga profil Tuanku Tambusai dapat dipahami lebih untuh dan komprehensif.

\section{B. Pendekatan teoritis.}

Sudirman, mengutip pendapat Abdul Munir Muslehan, dalam buku, Paradigma Intelektual Muslim, 1993 hal. 100 menjelaskan bahwa, pengertian dakwah sebagai suatu kegiatan sosialisasi Islam memiliki berbagai bentuk pengertian yaitu : a). mendorong manusia agar melakukan kebajikan dan mengikuti pentujuk, menyuruh berbuat kebajikan dan meninggalkan kemungkaran agar memperoleh kebahagiaan di dunia dan akhirat. b). Mengadakan seruan kepada manusia untuk kembali dan hidup menurut ajaran Allah dilakukan dengan penuh kebijaksanaan dan nasehat yang baik, c).mengubah umat dari satu situasi ke situasi yang lebih baik dalam segala aspek kehidupan dengan tujuan merealisasikan ajaran Islam dalam kehidupan, d). menyampaikan ajaran Allah dan Rasul untuk membuat manusia hidup sesuai dengan martabat, fungsi dan tujuan hidupnya. (FDK, 2007: 61).

Pemahaman lain, tentang dakwah secara defenitif dikemukakan oleh, S.M. Nasaruddin Latif memberikan defensisi dakwah adalah kegiatan dengan lisan atau tulisan dan lainnya yang bersifat menyeru, mengajak, memanggil manusia lainnya untuk beriman dan menta'ati Allah dan Rasulnya, sesuai dengan garis-garis aqidah syari'at serta akhlak Islamiyah.(Siti Muriah, 2000:4). Dengan pengertian ini, dapat difahami bahwa dakwah 
itu merupakan kegiatan yang memiliki unsurunsur kompleks yang berfungsi :

1. Dakwah berfungsi untuk menyebarkan Islam kepada manusia sebagai individu dan masyarakat sehingga mereka merasakan Islam sebagai rahmatan lil 'alamin.

2. Dakwah berfungsi melestarikan nilai-nilai Islam dari generasi ke genearsi berikutnya, sehingga kelangsungan ajaran Islam beserta pemeluknya tidak terputus.

3. Dakwah berfungsi korektif artinya meluruskan akhlak yang bengkok, mencegah kemungkaran dan mengeluarkan manusia dari kegelepan moral. (Moh. Ali Aziz, 2004: 58).

Dengan konsep dakwah yang demikian, dakwah dapat difahami dalam terminology, Islamisasi, dan pembaharuan. Term "pembaharuan" merupakan bagian integral dari konsep dakwah, meskipun pengertian yang dikandung oleh kata Pembaharuan, juga menyangkut dengan usaha untuk menyesuaikan faham-faham keagamaan Islam dengan perkembangan baru yang ditimbulkan kemajuan ilmu pengetahuan dan tekhnologi modern, Tapi juga Pembaharuan dapat diberi makna usaha-usaha untuk menyelaraskan realitas-realitas masayarakat Islam dengan konsep-konsep Islam, atau dalam bahasa lain disebut dengan Pemurnian agama, atau puritanisme.(Harun Nasution, 1975:23).

Penyebaran Islam di Nusantara tidak dapat dilepaskan dari aktivitas dakwah dan pembaharuan Islam. Kedua aspek ini merupakan suatu proses yang sangat penting dalam sejarah Indonesia. Meskipun disadari bahwa terdapat banyak masalah yang perlu dikaji lagi secara kritis untuk memahami proses perkembangan Islam tersebut lebih komprehensif.

Diantara beberapa factor yang cukup penting untuk dipahami dan dikaji dalam proses dakwah dan perkembangan Islam adalah menyangkut dengan kegiatan-kegiatan proses Islamisasi dan pembaruan Islam yang sesungguhnya adalah bagian dari watak Islam itu sendiri, yang dapat ditangkap dan dipahami oleh umat Islam melalui pemikiran-pemikiran para tokohnya.

Sesungguhnya bukanlah sesuatu yang paradox jika Islam, sebagai agama wahyu yang universal dan bertolak dari kesempurnaan dan keabadian doktrin menampakkan dirinya dalam keragamaan yang diwarnai oleh perjalanan sejarah dan situasi sosial kultural dari masyarakat pemeluknya. Meminjam ungkapan Prof Dr. Taufiq Abdullah, yang menyatakan bahwa, ketegangan antara doktrin yang abadi dengan manifestasi dalam kehidupan pribadi maupun social, merupakan factor utama dari dinamika Islam. Dalam sejarah Islam kelihatan ketika ketegangan itu tak lagi dirasakan maka priode kejumudan dan keterlenaan intelektual dan keterbelakangan sosialpun akhirnya muncul. Karena itu sesungguhnya dapat dipahami bahwa munculnya para pemikir, pembaharu, merupakan pertanda kesadaran tentang ketegangan yang kreatif antara doktrin yang abadi dan universal itu dengan manifestasi yang beraneka ragam.(Taufiq Abdullah,1987:1).

Senada dengan pemikiran Taufiq Abdullah, Azyumardi Azra lebih jauh mengemukakan bahwa memahami proses transmisi gagasan pembaharuan itu menjadi semakin penting dalam hubungannya dengan perjalanan Islam di Nusantara. Karena kawasan ini secara geografis terletak pada pinggran (periferi) dunia muslim, terdapat kecenderungan di kalangan sarjana dan peneliti modern untuk tidak memasukkan Nusantara (Indonesia) dalam pembaruan tentang Islam,dengan asumsi bahwa Islam kawasan ini tidak mempunyai tradisi keilmuan yang mantap.(Azyumardi Azra, 2007:xix).

Terlepas dari pemikiran yang demikian, fakta historis menunjukkan bahwa dinamika islam di nusantara tidak dapat dilepaskan dari kegiatan Islamisasi dan usaha-usaha pembaruan dan perbaikan yang dilakukan oleh para ulama yang tersebar di seluruh Nusantara dengan jaringan-jaringan yang tersedia.

Secara teoritis terdapat beberapa saluran yang dilakukan oleh para muballigh Islam dan para ulama dalam melakukan dakwah dan pembaharuan Islam, yang dapat diklasifikasi sebagai berikut :

1. Saluran perdagangan dan Pernikahan, seni dan Budaya.

Dalam teori-teori penyebaran Islam diketahui bahwa sejak awal dakwah Islam dilakukan melalui saluran-saluran perdagangan, dan pernikahan, akan tetapi metode dakwah ini pada umumnya dilakukan oleh orang-orang "asing" baik dari Arab, Gujarat, Cina, dll. Sementara itu saluran Seni dan budaya disamping banyak dilakukan oleh 
orang-orang "asing" tersebut, juga dilakukan oleh orang-orang Indonesia sebagai bagian dari metode Islamisasi, seperti wali songo di Pulau Jawa. Dan umumnya aktivitas dakwah melalui saluran ini sangat intens dilakukan pada masamasa awal Islamisasi Nusantara.(Wahyu Ilahi, 2007:155).

2. Saluran Pendidikan dan Penulisan Karya tulis.

Aktivitas pendidikan merupakan bagian penting dari proses Islamisasi dan pembaharuan Islam di Nusantara, yang mengambil bentuk pesantren. Secara historis pesantren dikembangkan guna keperluan dakwah dan syiar Islam. Dapat dikatakan lembaga pendididkan pesantren merupakan anak panah penyebaran Islam.(Wahyu Ilahi, 2007:182). Sementara itu penulisan karya tulis, telah menjadi satu bagian penting dari proses Islamisasi melalui karya tulis para ulama, setidak-tidaknya menurut UU.Hamdidy seperti inilah yang terjadi di Riau.(UU.Hamidy, 1996:146).

\section{Jaringan tasawuf dan tarekat-tarekat.}

Jaringan tasawuf atau tarekat, merupakan hal yang sangat penting terutama berkaitan dengan Islamisasi dan pembaharuan dalam Islam. A.H. John, yang dikutip oleh Azyumardi Azra, mengemukakan teorinya bahwa, para sufi memainkan peranan penting dalam penyebaran Islam di Indonesia, setiaknya sejak abad ke 13. Keberhasilan para sufi ini, didukung oleh kemampuan para sufi menyajikan Islam yang atraktif, (Azyumardi,2007:14), yang mampu menyelaraskan symbol-simbol ke Islaman dengan kemampuan penangkapan kultural dari masyarakat yang ingin dimasukkan ke dalam pangkuan Islam, meskipun terkadang harus dibiarkan munculnya penafsiran yang mungkin agak terpisah dari wahyu yang utuh dan abadi. Dengan begini maka terjadilan keragaman dalam manifestasi Islam. Dari perspektif point point tersebut di atas menggambarkan bahwa proses Islamisasi dan pembaharuan Islam dilakukan secara damai dan bukan dengan kekerasan.

Kajian Peran Tuanku Tambusai dalam akvititas dakwah dan pembaharuan Islam sangat layak dilakukan. Karena nilai informasi historis ini sangat penting dalam perkembangan khazanah budaya bangsa, juga beliau pejuang yang anti kolonial, yang menyelaraskan kegiatan perjuangannya melawan kolonialisme dengan aktivitas dakwah dan pembahruan Islam. Data historis yang ditemukan sebagaimana di tulis oleh Christin Dobbin menjelaskan bahwa Tuanku Tambusai adalah seorang Paderi, yang memiliki jaringan luas dan intensif dengan ulama-ulama Paderi di Sumatera Barat dengan tuanku Imam Bonjol dan Tuanku Rao.(Christeen Dobbin, 1992:221). Kelak jaringan ini akan berpengaruh besar terhadap proses dakwah dan pembaharuan Islam yang dilakukan oleh tuanku Tambusai sebagai ulama Paderi. Karena tentu tidak sulit untuk di mengerti sebagai seorang Paderi Tuanku Tambusai sebagai ulama tentu sangat akrab dengan reformasi keagamaan sebagaimana hal ini telah menjadi ciri dari kelompok Paderi. Dr.Karel

A.Steenbrink, yang mengutip hasil penelitian Schrieke sebagai usaha mengungkapkan reformisme Paderi, lebih lanjut mengemukakan bahwa disamping sebagai kaum ulama, mereka juga dapat dijuluki sebagai kaum cerdik pandai, (intelektual). (Karel A.Steenbrink, 1984:34), yang menjadi pemimpin keagamaan masyarakat. Karena itu Sebagai seorang ulama dan cendekiawan di masanya, sulit untuk menolak sebuah argument pemikiran bahwa tuanku Tambusai jelas memiliki kegiatan Islamisasi dan Pembaharuan Islam, walaupun sampai saat ini sangat sedikit tulisan tentang hal itu.

\section{Aktivitas dakwah dan ke pahlawanan Tuanku Tambusai.}

Sungguh menarik apa yang telah di jelaskan oleh UU Hamidy dalam bukunya Islam dan masyarakat Melayu di Riau, bahwa membicarakan tokoh Tuanku Tambusai dalam tingkah laku social budaya jelas menghadapi kesulitan besar. Sebab gambaran sejarah meskipun telah di rekam oleh peristiwa dalam bentuk catatan tahun, namun esensinya tetaplah bertumpu pada tokoh-tokoh yang telah memainkan peranan dalam kehidupan masyarakat dalam suatu waktu atau priodisasi tertentu. Kesulitan yang dihadapi dalam merekam tingkah laku sosial budaya Tuanku Tambusai terbentur pada minimnya literature dan keterangan yang bisa diperoleh untuk merekonstruksi bagian-bagian kehidupan beliau. Oleh sebab itu maka tulisan ini pada dasarnya bertumpu pada empat buah literature utama yaitu : Pertama 2 buku yang ditulis oleh; Umar Ahmad Tambusai yang berjudul ( 1). 
Hikayat Perjuangan Tuanku Tambusai, yang diterbitkan oleh Badan Kesenian Daerah Propinsi Riau tahun, 1978.(2). Perjuangan Tuanku Tambusai, yang diterbitkan oleh Pustaka As Pekanbaru,tahun 1981. Buku ketiga di tulis oleh H. Mahidin Said, dengan judul Rokan Tuanku Tambusai Berjuang, cetakan pertama tahun 1969, dan cetakan kedua tahun 1996, di cetak oleh Vista Indah Perinting Pekanbaru. Buku ke empat, ditulis oleh UU Hamidy, seorang Penulis aktif dan Budayawan Riau, yang berjudul : Islam dan Masyarakat Melayu di Riau, terbitan, UIR Press, Pekanbaru, tahun 1999. Kempat buku tersebut merupakan literature utama dalam tulisan ini ini yang digunakan untuk mengetahui tentang kehidupan dan perjuangan Tuanku Tambusai yang menjadi fokus tulisan ini.

\section{Biografi ringkas Tuanku Tambusai}

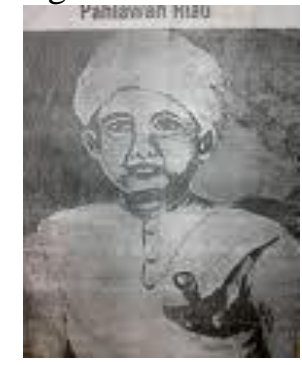

Gambar Tuanku Tambusai (ini menurut Sketsa Abdul Qohhar tahun 1838, seorang prajurit dan Murid Tuanku Tambusai yang menyertai beliau dalam penerangan melawan kolonial Belanda)

Pemabahasan tentang Tuanku Tambusai sungguh dirasa tidak tepat tanpa menyertakan kajian tentang Kerajaan Tambusai. Periodisasi sejarah kehidupan Tuanku Tambusai banyak melibatkan kerajaan Tambusai terutama, pada priode kelahiran, masa kanak-kanak, dan remaja. Tentu tidak berhenti disitu, beberapa priodisasi kehidupan dan dinamika politik kerajaan Tambusai tidak dapat dilepaskan dan menjadi bagian cukup penting dari sebagian yang melatarbelakangi kehidupan Tuanku Tambusai.

Dalam buku Sejarah Perjuangan Sulthan Muahammad Zainal Abidin, oleh Drs. Islamil Suko dkk,(2006:27) di jelaskan bahwa; Kerajaan Tambusai di awali pada sekitar penghujung abad IX kelompok manusia berasal dari tanah seberang /Semenanjung Melaya memasuki sungai Rokan yang bermuara di Bagan Siapi-Api. Perjalanan diteruskan menelusuri Sungai Rokan jauh ke hulu Batang
Sosa sampai disuatu tempat yang bernama Karang Besar. Tempat ini dianggap cocok dan baik untuk tempat pemukiman penduduk karena tanahnya datar, terletak di pnggir sungai, subur untuk perlandangan, sungai dan danaudanaunya kaya ikan dan di dalam rimbanya banyak terdapat binatang buruan. Kehidupan rakyatnhya adalah berladang berpindahpindah dan berpencar dari satu tempat ke tempat lainnya di tepi sungai Batang Sosa, sungai Rokan Kiri dan Rokan Kanan.

Demikianlah seterusnya habis tahun berganti tahun, negeri Karang Besar terus maju dan berkembang. Sistem pemerintahan masyarakat Karang Besar yang terdiri dari beberapa suku. dipimpin oleh masing-masing Datuk, dan Datuk-Datuk ini dipimpin oleh Datuk Bendahara. Setelah berjalan sekian lama system pemerintahan yang berbasis adat tradisi ini ternyata tidak dapat lagi dipertahankan, karena masing-masing datuk selalu memihak kepada masyarakat sukunya, yang mengakibatkan munculnya perselisihan dan pertikaian diantara penduduk.

Melihat gejala-gejala yang terjadi di masyarakat Karang Besar, maka segenap golongan penduduk Karang Besar, menyadari bahwa untuk kemuliaan, kejayaan, dan kemuliaan negeri Karang Besar mutlak memerlukan system pemerintahan dan aturanaturan yang harus dipatuhi oleh masyarakat. Karena itu mereka memerlukan system pemerintahan yang berdaulatkan Raja/ Sulthan.

Utusan Kerapatan masyarakat Karang Besar berangkat ke gunung hijau ( Kerajaan Pagaruyung=pen). Untuk memintak salah satu putra sultan Pagaruyung untuk menjadi raja di Karang Besar.Dengan pertimbangan baik buruknya demi memelihara kesejahteraan suatu negeri maka permohonan untusan dari Karang Besar dipenuhi oleh Sulthan Pagaruyung dengan berkenan mengaruniakan putra mahkota yang bernama Sulthan Mahyudin kepada utusan Karang Besar, setelah lebih dahulu di tabalkan dengan upacara istemewa dengan gelar Sulthan Mahyudin. (Ismail Suko,2006:28). Sulthan Mahyudin oleh masyarakat Karang Besar di beri gelar Muhammad Kahar, Raja I memerintah di kerajaan Karang Besar mulai tanggal 17 Muharram $271 \mathrm{H}(850 \mathrm{M})$ dan mangkat pada tahun $372 \mathrm{H}(951 \mathrm{M})$.

Pada masa pemerintahan Raja V Sulthan Syaifuddin, ibu kota kerajaan dipindahkan ke utara Dalu-dalu. Kemudian Ibu 
Kota Kerajaan di pindahkan lagi ke Dalu-Dalu dan ditetapkanlah Dalu-Dalu sebagai pusat kerajaan. Dan nama kerajaan pun berubah menjadi Kerajaan Tambusai.

Setelah Karang Besar ditinggalkan dan kembali pindah ke hilir, maka oleh orang Batak Angkola ( dulu : Tapanulis Selatan), sekarang Karang Besar yang letaknya saat ini berada dalam daerah Barumun (Sekarang Kabupaten Padang Lawas=pen ) (Karang Besar oleh orang -orang Barumun Padang Lawas (=pen) menyebutnya dengan Hapung. (H.Mahidin,S, 1996:9). Sekarang Hapung secara adminsitratif masuk (terletak) kedalam Kecamatan Sosa, Kabupaten Padang Lawas.

Dimasa Kerajaan Tambusai di perintah oleh Raja yang XIV yakni Sri Sulthan Ibrahim gelar duli yang dipertuan Besar, yang menjadi Wali Syarak di Tambusai adalah Imam Maulana Kali, seorang ulama yang berasal dari Rambah. Beliau terkenal sebagai seorang yang bijaksana dan lapang dada, Imam Maulana Kali menikah dengan seorang gadis Tambusai dari suku Kandang Kopuh, sebagai teman hidupnya. Dari pernikahan ini lahirlah seorang putra yang kelak mengisi dan menghiasi lembaran sejarah Indonesia. Seorang putera yang mempersembahkan sebahagian besar hidupnya mengangkat senjata untuk membela agama dan Ibu pertiwi, menentang penjajah Belanda, yaitu Tuanku Tambusai.

Tuanku Tambusai lahir dengan nama Muhammad Saleh. Di lahirkan di Kerajaan Tambusai (saat ini dinamakan dengan DaluDalu Kecamatan Tambusai di Kabupaten Rokan Hulu ), diperkirakan tanggal 5 November 1784. ( http://vkusral.blogspot.com /2011 ( 25-12-2012). Muhammad Saleh kecil didik dengan kasih sayang orang tuanya, namun kasih sayang ini tidak pernah diperlihatkan. Imam Maulana Kali menggembleng M.Saleh dengan disiplin yang ketat, dan pada usia tujuh tahun ayahnya mulai mengajarnya membaca al-Qur'an, dan ajaranajaran agama Islam terutama ilmu Fiqh, Muhammad Selh juga belajar tradisi-tradisi yang terdapat dalam lapisan masyarakat, belajar bersilat, menunggang kuda, dan mempergunakan senjata perang. Ketika Imam Maulana Kali (ayahnya) merasa bahwa seluruh ilmu pengetahuan yang ada padanya telah di ajarkan kepada anaknya, kemudian beliau mengirim M.Saleh ke Bonjol (Pasaman, Sumatera Barat) untuk melanjutkan belajar agama kepada Tuanku Imam Bonjol dan para Paderi di Bonjol dan di Rao. Karena pada saat itu Bonjol telah menjadi pusat pengajaran agama Islam.

Oleh para gurunya Paderi Tuanku Tambusai diberi gelar Pakih Saleh. Dan oleh Belanda karena perjuangannya yang gigih melawan Belanda diberi gelar, De Padriesche Tijger van Rokan ( Harimau Paderi dari Rokan). Tuanku Tambusai meninggal dunia di Seremban Malaysia pada tanggal 12 November 1882.

1. Bentuk dakwah dan perjuangan Tuanku Tambusai.

Satu hal penting yang dapat dipahami dari kajian sejarah Tuanku Tambusai yang ditemukan dalam literature-literatur adalah, bahwa sebagai seorang ulama Paderi dan hidup pada masa-masa perjuangan melawan kolonial Belanda, aktivitas keagamaan yang dilakukannya -terutama dengan kegiatan penyebaran Islam- sangat terkait dengan kegiatannya melawan penjajah Belanda. Oleh sebab itu dalam pembahasan selanjutnya kegiatan dakwah Tuanku Tambusaipun tidak dapat dilepaskan sama sekali dengan kegiatan perjuangannya mengusir penjajah Belanda.

Jika ditelusurui masuk dan berkembangnya Islam di Kerajaan-kerajaan Melayu, khususnya di Riau diketahui dan telah merupakan kesepakatan para sejarawan bahwa Islam masuk pada awalnya melalui jalur perdagangan.(Hasbullah, 2007:83). Yaitu pedagang-pedagang asing dari negeri-negeri Cina, India, dan Arab -Persia. Dan telah dijelaskan sebelumnya bahwa daerah Kuntu Kampar, merupakan daerah yang pertama memainkan peranan dalam sejarah Riau, karena daerah lembah sungai Kampar Kanan/ Kiri merupakan daerah penghasil lada terpenting di seluruh dunia dalam priode antara 500 sampai 1400 Masehi.(Mukhtar Luthfi, 1998: 271). Tentu tidaklah mengherankan kalau daerah ini pula yang mula-mula dimasuki agama Islam. Meskipun Islam telah masuk pada abad ke 7 atau ke 8 Masehi di Riau, namun penganut agama ini masih terbatas dilingkungan para pedagang dan penduduk kota di pesisir pantai. Hal ini disebabkan masih kuatnya pengaruh agama Budha yang merupakan agama Negara dalam kerajaan Sriwijaya waktu itu yang menyebabkan Islamisasi tidak berkembang, dan kondisi 
seperti ini berlangsung sampai abad ke 12 . (Mahidin Said, 2003:78).

Meskipun tidak diketahui dengan pasti kapan tahun masuknya Islam ke Rokan, khususnya Rokan Hulu, pengembangan Islam khususnya dikerajaan-kerajaan lima luhak (Tambusai, Rambah, Kepenuhan, Rokan IV Koto dan Kuntu Dars Essalam), selanjutnya dikembangkan oleh penguasa-penguasa kerajaan dan muballigh-muballigh atau tokoh agama atau kadi yang ada di kerajaan tersebut. Hasbullah (2007:83), menjelaskan bahwa Islamisasi yang dimulai dari kalangan atas yakni Raja atau Sulthan beserta keluarganya menjadi salah satu faktor penting dari keberhasilan Islamisasi.

Dari aktivitas Tuanku Tambusai dalam catatan sejarah dapat dipahami bahwa kegiatan dakwah beliau dapat dilihat dari dua aspek yaitu dari aspek pemurnian agama, dan dari aspek Islamisasi.

\section{a. Dakwah dalam bentuk pemurnian (Puritanisme) Agama.}

Terlepas dari perbedaan pemahaman terhadap konotasi dari kata "pemurnian" kaitan dengan agama tapi dari konsep"Dakwah Islam" "Pemurnian" memang merupakan bagian penting dari usaha -usaha Dakwah Islam. Karena pemurnian agama (Puritanisme) merupakan bentuk usaha untuk membersihkan pemahaman agama dari elemen: syrik, Khurafat, tahayul, dan pemahaman pemahaman yang dapat menodai keyakinan Agama.

Tuanku Tambusai sebagai seorang Paderi, juga banyak melakukan aktivitas dakwah dalam bentuk pemurnian terhadap ajaran-ajaran Islam yang ada di tengah-tengah masyarakat Kerajaan Tambusai.

Tuanku Tambusai sebagai seorang ulama, pejuang sekaligus merupakan mubaligh dan Reformer dalam pengembangan Islam khususnya di daerah Rokan hulu dan sekitarnya. Motivasi- motivasi dakwahnya,juga tidak dapat dipisahkan dengan apa yang dilakukan oleh orang -orang Paderi di Sumatera Barat, pemahaman agama yang memotivasi dakwahnya juga kurang lebih sama dengan motivasi dakwah Paderi yang berbasis pada aliran Wahabi, walaupun begitu menurut De Stuers masih terdapat kegiatan-kegiatan positif dari aktivitas Paderi, dan menurut Scrieke (1973) tidak sepenuhnya gerakan
Paderi sama dengan Wahabi, terutama dengan gerakan dakwahnya, kaum Paderi tidak selamanya menggunakan kekerasan ketika berdakwah dan mengembangkan Islam.(Karel A.Steenbrink, 1984:35).

Informasi- informasi penting tentang kegiatan dakwahnya diperoleh dalam potonganpotongan kecil tulisan sejarah Tuanku Tambusai, atau digali dari ide-ide yang tersembunyi dibalik uraian dan pemaparan kisah kepahlawanan beliau, yang ditulis oleh penulis dari kalangan sendiri, maupun tulisan tulisan asing yang kemudian akan dirangkai menjadi pemaparan tentang aktivitas dakwahnya khususnya di Rokan Hulu dan sekitarnya pada abad ke 19.

Satu waktu, ketika Duli yang di pertuan besar memerintah, memintak agar Pakih Saleh dijemput ke Rao (Sumbar) dan dibawa kembali ke Dalu-dalu (Rokan Hulu) untuk menyelesaikan sebuah masalah keagamaan yang dihadapi oleh kerajaan Tambusai.

Setelah masalah yang harus diselesaikan itu dapat didudukkan sebagai mana mestinya, Pakih Saleh tidak segera kembali ke Rao, beliau mendirikan surau terpisah dengan negeri lama, kehilir pasar Dalu-dalu sekarang dimana terakhir beliau mendirikan kubu pertahanan. Pangkalan tempat pemandianya di pinggir batang sosa ada pohon - pohon besar berrakar-akar laksana ular tidur mempertahankan keruntuhan tebing. Pohon tersebut hidup di air dan didarat bernama daludalu, kemudian resmi bernama Negeri DaluDalu. Disini beliau mengembangkan Ajaran agama Islam (di Dalu-dalu) membuka perguruan membaca Qur'an, memberikan tabligh-tabligh dan penyiaran agama secara giat. Hal ini dapat berjalan dengan lancar, karena memang penduduk Dalu- dalu dan sekitarnya sudah agak lama memeluk Agama Islam. Lagi pula tantangan dari kaum adat seperti yang terdapat di Sumatera Barat tidak terdapat, hususnya di Dalu-dalu dan umumnya di Kerajaan Tambusai. Meskipun demikian Pakih sudah tetap konsekwen menjalankan Dakwah Islam, melarang perjudian, menyabung ayam, dan minum-minuman keras serta menhisap madat. (Mahidin Said, 2003:31).

Sebagai seorang ulama paderi, yang telah banyak makan asam garam aliran (faham) ini, karakteristik dakwah yang dilakukannya banyak terinsfirasi oleh pemahamannya 
terhadap ilmu- ilmu yang di berikan gurunya (para paderi) di Bonjol, maka gerakan dakwahnya sebagaimana sifat dan gerakan Wahabi memberikan dimensi- dimensi pembaharuan ke tengah-tengah masyarakat.

Meminjam uraian UU,Hamidy: bahwa gerakan paderi sebagai kekuatan untuk membersihkan akidah islam yang karut dengan berbagai tradisi syirik, (yang berasal dari lanjutan kehidupan jahiliyah masa silam,) paderi memberantas berbagai kebiasaan seperti menyabung ayam, merokok, menyembah kuburan dan berbagai upacara primitive lainnya, dan menganjurkan memeluk Islam dengan bersih, memakai pakaian putih, memanjangkan janggut dan mencukur kepala. Kadar aliran ini yang "diminum" Muhammad Saleh dalam perguruannya akan menjadi bagian yang penting dalam cara dia menafsirkan realitas serta akan amat berpengaruh terhadap tindakanyangdiambilnya.(UU.Hamidy,1999:53)

Sebagai seorang Paderi yang belajar langsung ke Sumatera barat, Tuanku Tambusai memahami bahwa "surau" merupakan institusi (lembaga) utama untuk melakukan transformasi ajaran- ajaran Islam kepada masyarakat, "surau" yang didiriikan oleh Tuanku Tambusai di pinggir sungai batang sosa tidak hanya menjadi tempat melaksanakan ibadah, akan tetapi juga merupakan sarana belajar ke Islaman. Hal ini sesuai dengan kondisi pada masa-masa itu -+ abad ke 19 konsep surau Minangkabau tidak hanya tempat melaksanakan kegiatan ibadah, akan tetapi merupakan komplek bangunan yang didalamnya terdapat masjid tempat beribadah, bangunan tempat belajar, dan bangunan surausurau kecil yang sekali gus menjadi pemondokan murid- murid yang belajar disana. Di lembaga surau ini berlangsung transmisi ilmu pengetahuan keislaman, internalisasi nilai -nilai serta transformasi budaya. Herman M.Pd, (2010:2), melihat posisi surau ini dari perspektif dakwah Islam, Peran surau, selain sebagai tempat pengembangan Islam dan ilmu- ilmu keIslaman, juga tempat dimana terjadi proses sosialisasi dan internalisasi budaya masyarakat, sehingga Islam mampu mewarnai hampir seluruh aspek kehidupan masyarakat dan budayanya.

Surau Tuanku Tambusai telah difungsikan sebagai tempat Ibadah dan sekaligus sebagai sarana belajar ke Islaman, di kerajaan Tambusai Dalu-dalu. Surau bagi
Tambusai merupakan lembaga dakwah dan pendidikan Islam saat itu. Surau telah menjadi sarana utama dalam transformasi dan internalisasi ajaran- ajaran Islam kepada masyarakat, Tambusai, dan khusus kepada murid-muridnya disamping sebagai sarana ibadah dan tempat belajar ajaran Islam, surau menjadi sarana penggemblengan mental dan fisik sehingga menjadi prajurit yang tangguh.

UU.Hamidy,( 1999:57 ) lebih lanjut menjelaskan bahwa; Suatu hal yang menarik dalam tiap lembaga dakwah dan pendidikan yang didirikan oleh Tuanku Tambusai ialah, bagaimana murid- muridnya tidak hanya mendapat pelajaran agama Islam dan budi pekerti, tetapi juga sekaligus telah di tempah menjadi seorang prajurit yang militan, tentu banyak dipengaruhi oleh kemampuan ulama ini dalam memberikan pelajaran dan pemahaman dengan kadar yang memadai, lalu dilengkapi dengan penampilan kredibilitas dan integritas pribadi yang alim, jujur, tegas, sehingga berwibawa terhadap murid- muridnya.

Keberhasilan Tuanku Tambusai menempah murid- muridnya menjadi prajurit menjadi faktor penting bagai mana beliau ini akhirnya menjadi seorang panglima perang lawan Belanda antara 1833 - 1839 M. Ulama ini telah berhasil membentuk pasukan sekitar 7000 orang. Disamping itu telah dapat pula dibinanya beberapa panglima sebagai pembantunya seperti Imam Perang Muhammad Jawi, H. M. Saman, Jumadil Alam dan Kali Alam, Abd. Kohar.

b. Dakwah Islam dalam bentuk Islamisasi.

Salah satu kegiatan penting dari Tuanku Tambusai (Pakih Saleh) adalah penyebaran Islam ke daerah-daerah yang sama sekali belum "disentuh" oleh ajaran Islam. Umar ahmad Tambusai (1981:25) menjelaskan ketika para guru-gurunya ulama Paderi merasa bahwa Pakih Saleh sudah cukup lama belajar agama, mereka mewajibkan beliau mengajar dan mengembangkan ajaran Islam. Beliau ditunjuk untuk melaksanakan tugasnya di daerah yang paling sukar yakni daerah Toba dan sekitarnya, dimana penduduk masih menganut agama pelbegu, salah satu kepercayaan animisme ditanah Batak. Bertahun-tahun beliau menyampaikan seruan agama Islam kepada penduduk, bersaing dengan missi Khatolik dan zending Kristen. 
Setelah merasa cukup lama, dan tidak berhasil mengembangkan syiar Islam di Tanah Batak, bahkan beliau mendapat tantangan keras dan dituduh sebagai pengacau oleh kaum Bangsawan, akhirnya Pakih Saleh kembali ke Rao. Dan di daerah inilah (Rao ) Pakih Saleh meneruskan tugas dakwahnya bersama dengan sahabatnya pemuda Batak si Pokki Nangolngolan yang pada masa itu telah diambil menantu oleh yang dipertuan Negeri Rao dan bergelar Tuanku Rao. Beliau (Tuanku Tambusai) mengembara keluar masuk kampung, Rao, Air Bangis, sampai ke Padang Lawas, mengajar orang yang belum pandai, dan belajar dari orang-orang yang lebih pandai.

c. Dakwah Islam dan pejuangan bersenjata, di Rao, Angkola /Barumun dan Dalu-Dalu.

Variasi penyebaran dan perkembangan Islam di Indonesia pada umunya, sebagaimana teori Islamisasi yang telah lazim di fahami, biasanya melalui saluran perdagangan, pernikahan, pendidikan, dan penulisan karyakarya tulis maupun pada bidang- bidang sastra.

Sedikit agak berbeda dengan apa yang dilakukan oleh Tuanku Tambusai (Pakih Saleh), dalam perjuangannya mengembangkan Islam. Sebagai seorang Ulama Paderi, muballigh dan tokoh pejuang, lembaga pendidikan "suraunya" dapat menjadi institusi pendidikan agama dan sekaligus militer bagi pejuang-pejuang Paderi (murid-muridnya), untuk persiapan menghadapi Belanda. Baginya Islam memiliki prinsip kesempurnaan yang tidak terdapat di dalamnya pemisahan antara berbagai aspek dan bidang-bidang kehidupan tertentu dengan yang lainnya. Karena itu bagi Tuanku Tambusai berjuang melawan Belanda adalah dakwah yang harus dilakukan. Akan tetapi dalam konteks ini tidaklah dimaksudkan bahwa. Tuanku Tambusai mengembangkan Islam dengan pedang.

Meskipun dia salah seorang dari kelompok Paderi tapi Tuanku Tambusai sendiri digambarkan sebagai seorang yang lemah lembut dari pada Tuanku Rao (atau Paderi yang lainnya). dan kelembutan ini makin meningkat setelah ia bersama beberapa Paderi yang lain menunaikan ibadah haji kira -kira pada tahun 1829. Tuanku Tambusai menyadari kemunduran kaum Wahabi di Arabia, dan menyadari perbedaan pandangan beberapa cendekiawan tentang jihad. Dia kembali kirakira pada tahun 1831 untuk melarang penggunaan kekerasan dan perampokan dalam usaha mengislamkan orang. Tuanku Tambusai membawa sejumlah buku untuk mendukung pernyataannya.(Christeen Dobbin, 1992:224).

Tuanku Tambusai memiliki karakteristik pribadi sendiri, bahwa meskipun dia dibesarkan dengan ajaran-ajaran Paderi, tapi dia berbeda dengan guru-gurunya. Dengan kecerdasannya dia bias melihat dan memahami serta menganalisis mana yang terbaik untuk dakwah Islam. Kekerasan menjadi pilihan terakhir jika tidak memungkinkan dengan dialog dan pendidikan.

Dan telah dijelaskan dalam awal uraian ini, bahwa untuk memahami dakwah Islam yang dilakukan oleh Tuanku Tambusai, tidak dapat difahami dengan utuh tanpa melihat bagian-bagian dari perjuangannya melawan Belanda. Semangat dan motivasi Tuanku Tambusai dalam perang dengan Belanda tidak terlepas dari pamahamannya bahwa melawan Belanda dan mengusir Belanda adalah bagian dari Jihad dan Dakwah. Dalam literatureliteratur yang membahas tentang Tuanku Tambusai sulit menemukan dan memetakan posisi dan perannya sebagai ulama, muballigh, dan sebagai pejuang yang terus bertempur melawan Belanda, semuanya menyatu dalam diri Tuanku Tambusai. Tidak ada jalan lain, untuk memahami kegiatan dakwahnya, kecuali dengan melakukan analisis dan merekonstruksi dari sikap, pandangan, dan pendiriannya terhadap kegiatan perang melawan Belanda. Secara khusus motif-motif agama yang digunakannya sebagai pendorong dan memotivasinya untuk terus berjuang memerangi Belanda.

Sebagaimana ditemukan dalam sejarah hidupnya, Tuanku Tambusai berjuang mengembangkan agama Islam ini telah melampaui batas-batas geografis kerajaan Tambusai di Dalu-dalu Rokan Hulu pada saat itu, Tapanuli Selatan (bahkan Tapanuli Utara) Sumatera Utara, dan Daerah Dalu-dalu, Pasir Pangaraiyan di Propinsi Riau. (UU.Hamidy, 1996: 56).

1). Dakwah Islam dan Pertempuran di Rao.

Semakin meningkatnya pertentangan dan pertempuran antara kaum Paderi dengan Belanda di Sumatera Barat, mendorong Tuanku Tambusai menyusun barisan dan kekuatan guna membantu guru-gurunya dan temannya sesame Paderi di Sumatera Barat. 
Maka Kurang lebih pada bulan Februari 1830 (1831), Tuanku Tambusai dan pasukannya tiba di Rao. Rao bagi Taunku Tambusai adalah tempat yang sangat dikenal. Di Rao dan Bonjol di belajar agama Islam bersama temannya Tuanku Rao, kepada guruguru mereka para Paderi. Dari segi strategi dakwah dan strategi perang, Rao menempati posisi yang sangat strategis karena bisa menjadi jalan dan pintu gerbang masuk ketiga jurusan, yakni ke Minangkabau (arah ke Selatan), ke Tapanuli (arah ke Utara) dan ke Luhak Tambusai /Riau (arah Timur). Rao menjadi penting bagi Paderi, dan juga bagi Belanda. Bagi Paderi Rao disamping menjadi pintu gerbang pengembangan Islam ke tanah Batak (mandailing dan Angkola-Padang Lawas), juga menjadi daerah sumber perdagangan dan pembiayaan Paderi. Karena itu setelah lembahan alahan panjang ( Bonjol), Paderi menetapkan kekuasaanya di lembah Rao. Bagi Belanda jelas motifnya adalah emas dan penguasaan perdagangan.

Pada bulan Juni 1832 sepasukan tentara Belanda dari Jawa tiba di Padang, langsung diberangkatkan ke Rao dipimpin oleh seorang opsir Mayor van Amerongen, dan akhirnya perang besar tidak dapat di elakkan. Kekalahan demi kekalahan di alami oleh pasukan Belanda, yang pada akhrinya meminta bantuan ke Padang. Ketika Rao dapat dikuasai Belanda di bawah pimpinan van amerongen pada oktober 1832, Belanda menukar nama Rao dengan Fort Amerongen (Benteng Amerongen). Di Rao ditempatkan pasukan Belanda yang cukup terlatih dibawah pimpinan oleh Letnan Engelbrecht, Letnan Logeman dan Popye.

Dengan jatuhnya benteng Rao, Tuanku Tambusai mengundurkan diri ke-arah Barat bersama pengikut-pengikutnya, dan segera dapat mengkonsolidasi dan mengkordinir pasukannya. Kekuatannya bertambah besar setelah orang-orang Mandailing (kebanyakan adalah bekas muridnya) turut bergabung dalam pasukannya. Persenjataan di tambah, kampanye anti Belanda di kobarkan ke segenap pelosok negeri bahwa perang lawan Belanda adalah Jihad karena Belanda adalah orang Kafir, maka mati dalam membela dan mempertahankan agama Islam, berperang lawan Belanda adalah mati syahid.(Umar Tambusai, 1978:41).

Ungkapan, himbauan dan semboyan tersebut, dapat di analisis dan di interpretasikan menunjukkan bahwa bagi Tuanku Tambusai perang melawan Belanda adalah kegitan dakwah yang harus dilakukan. Suruhan dan kewajiban agama menjadi motif yang mendasari dalam setiap penentangan terhadap Belanda. Perang terhadap Belanda adalah suruhan Dakwah yang harus dilakukan tanpa kompromi.

Mengikuti ulasan UU. Hamidy, yang menyebutkan bahwa dimata Tuanku Tambusai, Belanda dan kaum adat hendak berkuasa untuk kepentingan duniawi yang identik dengan pemuasa hawa nafsu, sedangkan Taunku Tambusai hendak memimpin ummat menjadi hamba Allah yang berbuat baik untuk dunia dan akhirat. Belanda dalam pandangan ulama ini tidak lain daripada thagut, penguasa yang mendewakan dirinya. Suatu hal yang tidak mungkin diterima diterima oleh Tuanku Tambusai sebagai ulama yang hendak membersihkan akidah Islam dari tradisi-tradisi dan perbuatan yang bertentangan dengan agama Islam.(UU.Hamidy,1996:60). Dan dengan pemikiran yang demikian maka Belanda dan pendukung-pendukungnya wajib diperangi karena tidak dapat diajak lagi ke jalan yang benar yang sesuai dengan syari'at Islam. Karena itu peperangan menjadi bagian dari dakwah dalam bentuk yang ekstrim.

Pemikiran dan pendirian yang seperti itu dapat dipahami berawal dari ke dalaman pemahaman Agama yang dimilikinya yang ditawarkan oleh guru- gurunya para Paderi, hasil olahan pengalamannya sendiri maupun pengetahuan- pengetahuan yang diperolehnya semasa ia berada di Makkah, oleh sebab itu semua aktivitas peperangan yang di lakukannya merupakan kewajiban dakwah yang diperintahkan oleh Allah yang melalui syariat'nya.

Kegigihan,ketangguhan, kecerdikannya dalam setrategi perang yang dimotifasi oleh kewajiban dakwahnya, juga yang membuatnya mampu menolak usulan perundingan yang di usulkan oleh pimpinan benteng Amerogen di Rao Engelbrecht, dalam sepucuk surat balasan Tuanku Tambusai menulis,"neen, Amerongen wat helpen ons gebeden. Het onrecht heft te lang geduurd. De Inlander van Tambusai en Mandahiling, en zijn hoofd en de luhahgemente vormen van oudds den kleinen-man, de dienstbaren, die dus nedering te houden is, overigens de belastingbetaler bij uitnemendheid. Neen, Amerogen. Tegen wil en dank bevinden zich de silent-Djawian ook in de 
smeltkroes...." ( Tidak Amerongen. Tidak perlu mengharapkan belas-kasih. Kezaliman telah berlangsung terlalu lama. Bumi putera dari Tambusai dan Mandailing, kepala dan luhaknya semenjak dahulu merupakan orang hina. Siorang patuh, yang oleh sebab itu ma uterus di hina selama-lamanya, pembayar pajak yang paling ta'at. Tidaklah Amerongen, mau tak mau orang jawi yang tenang itu menggelegak dalam kancah pergolakan...."( Umar Tambusai, 1978: 43).

Bagi Tuanku Tambusai kedatangan, dan tindakan Belanda dengan dalih dan atas nama apapun adalah suatu kezaliman yang harus di basmi dari bumi Indonesia. Kezaliman tidak mendapat tempat dalam syari'at, dan juga masyartakat Indonesia yang memegang teguh syari'at. Karena ketangguhan, kecerdikan Tuanku Tambusai melawan Belanda di daerah Rao dalam menggempur benteng (Fort) Amerongen, akhirnya Engelbrecht, dan pasukannya menerima laporan dari mata-mata yang dikirimnya ke dalam lasykar Tambusai, menyebut Tuanku Tambusai sebagai, Padriesche Tijger van Rokan (Harimau Paderi yang berasal dari Rokan). Dalam akhir laporannya disebutkan :

Een der indrukken, die ik reeds lang, voordat ik inMandailing kwam, had is daar zeer versterkt, ni. Dat zeis een Padriersche Tigjer een Padriesche Tijger van Rokan. ( Suatu kesan yang telah mendalam dalam diri saya, lama sebelum saya datang ke Mandailing bertambah keras setelah saya disana, yakni bahwa dia adalah seekor Harimau Paderi yang berasal dari Rokan).( Umar Tambusai, 1978:42). Demikian dakwah Islam yang dilaksanakan oleh Tuanku Tambusai di daerah Rao (Sumatera Barat).

2). Dakwah Islam di daerah Angkola dan Barumun (Padang Lawas).

Aktivitas dakwah dan pengembangan Islam yang dilakukan oleh Tuanku Tambusai di daerah Angkola dan Padang Lawas, sesungguhnya tidak jauh berbeda dengan yang dilakukannya di daerah -daerah lain. Beliau berdakwah sambil bertempur dengan Belanda. Baginya perang adalah dakwah yang harus dilakukan melawan orang-orang kafir yang menindas ummat Islam dan tanah air. Aktivitas dakwah Tuanku Tambusai ke daerah Tapanuli Selatan dan Angkola telah mulai ketika dia masih belajar di Rao dan Bonjol. Gurunya para Paderi menunjuknya untuk melaksanakan tugas dakwah dan mengembangkan ajaran Islam ke daerah yang paling sukar yakni daerah Toba dan sekitanya dimana penduduk masih menganut pelbegu,( salah satu kepercayaan Animisme) di tanah Batak. Bertahun-tahun beliau menyampaikan seruan agama Islam ke Tanah Batak namun kurang berhasil. Beliau terpaksa bersaing dengan missi Katolik dan Zending Kristen yang memiliki biaya berlimpah dan berhasil menarik penduduk dengan memberikan bantuan pendidikan, kesehatan, dan kesejahteraan umum. (Umar Tambusai, 1978:25). Meskipun demikian Pakih Saleh (Tuanku Tambusai ), yang keras hati itu, tak jemu-jemu terus berdakwah dan mengembangkan syi'ar Islam kepada penduduk Batak, hingga akhirnya beliau mendapat perlawanan dan tantangan terutama dari kaum Bangsawan. Merasa dirinya terancam dia kembali ke Rao. Di daerah ini dia kembali meneruskan tugasnya berdakwah mengembangkan ajaran Islam bersama sahabatnya Sipongki Nangolngolan yang pada masa itu telah diambil menjadi menantu oleh Yang dipertuan Negeri Rao, dan bergelar Tuanku Rao.

Dengan jatuhnya benteng Rao ke tangan Belanda, Tuanku Tambusai melanjutkan dakwah dan perjuangannya ke Angkola Barumun sambil terus melakukan perlawanan dan pertempuran dengan Belanda. Dalam bukunya Rokan Tuanku Tambusai Berjuang, H, Mahidin Said (1997:32) menjelaskan bahwa sebenarnya Tuanku Rao dan Tuanku Tambusai telah membagi garis perjuangan keduanya; dalam hal ini Tuanku Rao berdakwah melalui padang sidempuan, dan T.Tambusai berdakwah melalui Padang Lawas, Portibi/ Gunung Tua, Bilah Panai dan bertemu di Sipirok. Hal ini juga ditegaskan oleh Christeen Dobbin bahwa Tuanku Rao bukan satu-satunya pemimpin Paderi yang mempunyai missi mengislamkan orang-orang Batak. Diperbatasan Timur tanah Batak muncul pemimpin lain Tuanku Tambusai yang lebih dikenal dari pada Tuanku Rao, karena ia sering disebut dalam laporan Belanda.(Christeen Dobbin, 1992:220).

Karena di Angkola dan Barumun penduduknya telah memeluk agama Islam, malah ada diantaranya bekas murid-murid Tuanku Tambusai, maka kedatangan pasukan Tuanku Tambusai ke daerah ini mendapat sambutan yang baik. Apalagi banyak tentara Tuanku Tambusai berasal dari daerah Angkola 
dan Barumun, maka kedatangan mereka mendapat simpati dari rakyat setempat. Karena dakwahnya yang lembut, dan pendekatannya yang simpatik banyak para pemuda-pemuda Mandailing, Angkola dan Barumun segera masuk jadi tentara Tuanku Tambusai.

Untuk meluaskan daerah perjuangan dan dakwahnya, Tuanku Tambusai berusaha merebut hati rakyat Batak ini,- dengan cara persuasive - terhadap pemuka-pemuka masyarakat dan pemuka adat, (antara lain Sutan Guru Tamiang), mempelajari adat istiadat setempat, memberikan penerangan agama, dan memberikan petunjuk dan nasehat yang berguna kepada penduduk. Beliau pandai membawa diri dan menyesuaikan dengan adat setempat, yang pada akhirnya beliau menjadi orang terpandang dan disegani, dan sebagai seorang Ulama Islam yang sangat di hormati dan berpengaruh.

Karena simpati rakyat telah demikian besar terhadap Tuanku Tambusai, ahirnya beliau "diambil" sebagai keluarga Batak (Angkola-Barumun-Mandailing) dan dimasukkan ke dalam marga Harahap, salah satu marga yang terhormat dalam keluarga Batak. Karena penghormatan, terhadap beliau demikian besar, orang Batak (Angkola dan Barumun) tidak berani menyebut namanya "Tuanku Tambusai", karena dianggap nama asli beliau. Nama panggilan beliau di daerah itu adalah " Ompu Baleo". Dan Menurut Abd.Muin orang Gunung Tua /Portibi, sebutan "ompu baleo" atau "baleo" memang husus digunakan untuk orang yang sangat dihormati atau di tuakan. (Wawancara : Abd.Muin, 25-92013). Sampai saat ini Panggilan "Ompu baleo" tidak dikenal di daerah Mandahiling ( sekarang, meliputi kabupaten Mandailing Natal).

Meskipun tidak bisa dipastikan siapa yang membawa Islam pertama kali ke daerah Angkola-Barumun, tapi tidak bisa diabaikan Tuanku Tambusai memberikan kontribusi yang besar dalam pengembangan Islam selanjutnya. Seperti telah di uraikan sebelumnya terdapat beberapa murid Tuanku Tambusai yang turut mengembangkan Islam di Angkola -Barumun sebelum Tuanku Tambusai datang dengan pasukannya. Dan ketika Tuanku Tambusai sampai disana mereka rela dan bersedia menganut asas Paderi, (yang mungkin telah disemaikan oleh murid-muridnya sebelumnya) dan kepala-kepala desanya bersaing mendapatkan gelar Kadi (gelar yang diberikan dan diangkat Paderi kepada pemimpin setempat yang menerima azaz Paderi)., terlepas dari motif yang mendasari mereka.

3). Dakwah dan Benteng tujuh lapis.

Peristiwa sejarah masa lampau manausia hanya dapat dipercayai dengan adanya bukti-bukti sejarah. Tuanku Tambusai meninggalkan bukti dan fakta sejarah yang jelas (hard fact), baik berbentuk tulisan yang ditulis orang yang berhubungan langsung sezaman denganya maupun sesudahnya, seperti tulisan Abdul Qohar pada tahun 1838 yang merupakan murid dan tentara Tuanku Tambusai.

Salah satu bukti penting dari peninggalan sejarah Tuanku Tambusai adalah benteng (fort=Belanda). Benteng tersebut bernama "Kubu aur duri", tapi oleh masyarakat disebut dengan benteng tujuh lapis. Benteng ini sangat kokoh dan unik. Disebut unik karena benteng ini memiliki persamaan dan perbedaan dengan benteng Tuanku Tambusai yang lain. Tapi saat ini yang dapat dilihat hanyalah hamparan tanah yang cukup luas yang dikelilingi oleh tembok-tembok perbukitan tanah yang sengaja di buat. Ketinggian tembok tanah tersebut pada bagian -bagian tertentu saat ini, tidak kurang dari 5 sampai 6 meter, dengan ketebalan tembok ada yang mencapai 2 sampai 3 meter, dan mungkin lebih. Tapi karena erosi tanah selama ratusan tahun dan tidak adanya perawatan banyak bagian tembok perbukitannya yang amblas ke sungai Batang Sosa, dan sebagian lagi dirusak oleh masyarakat setempat yang tinggal dalam lokasi benteng.

Uniknya lagi benteng ini setiap tembok perbukitan dikelilingi oleh parit yang dalam dan lebar, diperkirakan tidak kurang dari 7 hingga 10 meter, dan lebar pada permukaan mencapai antara 2 sampai 3 meter bahkan mungkin lebih. Parit-parit ini mengelilingi semua tembok perbukitan, dan langsung berhubungan dengan sungai Batang Sosah.

Mhd. Ja'far (Wawancara: 3-10-2013) yang lahir dan dibesarkan di kompleks benteng tujuh lapis 40 tahun yang lalu, menjelaskan bahwa, menurut cerita orangtuanya yang diceritakan secara turun temurun kepada mereka bahwa dalam benteng tersebut dulu banyak rumah-rumah seperti kampung yang didiami oleh prajurit dan muridmurid Tuanku Tambusai. Sebagai ulama di benteng tersebut sekaligus dijadikan Tuanku Tambusai sebagai tempat untuk 
mengembangkan ajaran -ajaran Islam kepada murid-murid dan tentaranya.

Sepertinya keberadaan parit tersebut setidaknya memiliki dua fungsi 2 fungsi ganda, Pertama ; berfungsi sebagai parit pertahanan, untuk menghambat musuh (Belanda) masuk dan menguasai benteng. Kedua, parit memiliki fungsi yang sangat urgen untuk memenuhi kebutuhan (supply) air ke dalam benteng. Sebuah strategi yang cerdik, brilliant. Ditambah lagi di atas tanah perbukitan ditanami bamboo berduri (aur duri), yang sangat rapat, sehingga tidak ada jalan masuk ke dalam benteng kecuali pintu utama yang dipasangi papan tebal berlapis dan menyilang, atau melalui jalan rahasia. Sampai saat ini masih terdapat beberapa rumpun bamboo berduri di atas tembok perbukitan bengteng.

Seorang pejabat Belanda kemudian melukiskan dalam tulisannya bahwa benteng tujuh lapis ini sebagai benteng pribumi yang paling teratur yang pernah di jumpai di pantai barat Sumatera...... (Christeen Dobbin, 1992:221).

Namun sangat disayangkan hanya sedikit dari sekian pengarang yang menyebut tentang keadaan benteng Tuanku Tambusai ini, seolah-olah terbenam oleh cerita heroic lainnya. Tinggallah benteng tujuh lapis hanya saksi bisu, gundukan tanah, semak belukar, lokasi yang angker dan akhirnya hampir terlupkan.

Kerisauan ini belum terlalu mengecewakan karena masih ada pengarang Belanda, H.J.J.L. Ridder de Stuers plada tahun 1849 hingga 1950 menerbitkan bukunya dengan judul De vestiging en uitbredingder Nederlanders ter Weskust van Sumatera. Dalam buku ini cukup banyak informasi terutama mengenai schets atau denah benteng Tuanku Tambusai bahkan dilengkapi dengan ukuran dan jaraknya.(H.Ridwan Malay, 2007).

Berikut gambar beberapa bagian benteng Tujuh Lapis Tuanku Tambusai yang masih tersisa :

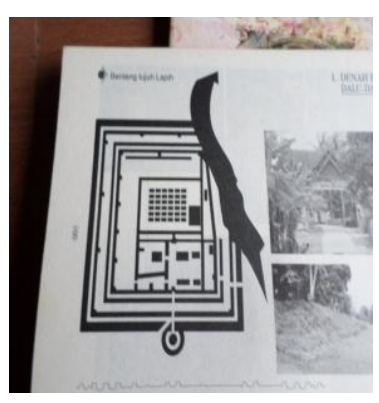

Gambar: 1. Denah benteng Tujuah lapis menurut Denah De Stuers 1849. (Dengan latar Belakang rumah penduduk saat ini di kompleks benteng. Terlihat tembok Benteng perbukitan yang di jebol untuk jalan kerumah penduduk).

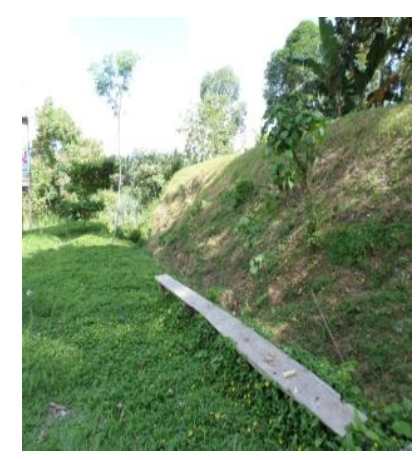

Gambar:2. sebagian Tembok benteng dengan tanah perbukitan yang dibangun sekeliling benteng. (dibelakang tembok perbukitan ini adalah parit dalam dan curam dengan kedalaman sampai 10-15 meter mengelilingi benteng dan langsung berhubungan dengan sungai Batang Sosah)

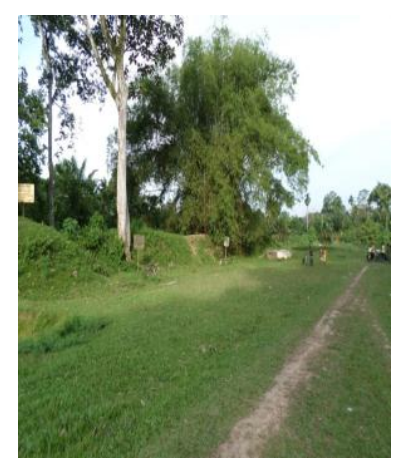

Gambar : 3. satu sisi benteng tujuh lapis pada lapisan ke 5 dengan Hamparan tanah luas dikelilingi oleh tembok perbukitan, diatasnya masih berdiri bambu berduri. (Tembok perbukitan tersebut dikelilingi oleh parit dalam dan lebar yang langsung berhubungan dengan sungai Batang Sosah)

Berkaitan dengan kontribusi benteng ini dalam aktivitas dakwah Tuanku Tambusai, Sampai saat ini memang tidak ada data yang tertulis yang diperoleh mengenai peran benteng ini dalam peangembangan Islam (dakwah) di Dalu-Dalu. Tapi dapat diyakini secara logis benteng ini tentu digunakan beliau juga disamping sebagai alat pertahanan tapi juga sebagaimana benteng-benteng paderi, digunakan untuk sarana pengembangan Islam minimal kepada murid-murid dan tentara- 
tentaranya dan lingkungan sekitar. Sebagai seorang ulama benteng tujuh lapis diyakini digunakan untuk membina dan membangun kehidupan keagamaan masyarakat di sekitarnya.

Hal ini disampaikan juga oleh Mhd. Ja'far (Wawancara: 3-10-2013) yang lahir dan dibesarkan di kompleks benteng tujuh lapis 40 tahun yang lalu, dan beberapa kali ikut seminar tentang Tuanku Tambusai, menjelaskan bahwa, menurut cerita orangtuanya yang diceritakan secara turun temurun kepada mereka bahwa dalam benteng tersebut dulu banyak rumahrumah seperti kampung yang didiami oleh prajurit dan murid-murid Tuanku Tambusai. Sebagai ulama di benteng tersebut sekaligus dijadikan Tuanku Tambusai sebagai tempat untuk mengembangkan ajaran -ajaran Islam kepada murid-murid dan tentaranya.

Muhammad Ja'far seorang anak Tambusai Asli, lahir dan dibesarkan di kompleks Benteng tujuh :Lapis, melanjutkan bahwa, Sampai saat ini kata beliau benteng Tuanku Tambusai tidak boleh digunakan sebagai tempat melakukan hal-hal yang tidak benar. Hamparan tanah luas di dalam kompleks benteng sekarang ini memang di gunakan oleh masyarakat terutama para pemuda sebagai tempat kegiatan-kegiatan. Tapi jika dilakukan tempat pacaran atau hal yang lain yang negative misalnya biasanya yang melakukan akan kesurupan dan bisa jadi mereka akan pingsan. Wallahu a'lam.

\section{Kesimpulan.}

Dari kajian yang telah dilakukan dapat diambil kesimpulan yaitu, Tuanku Tambusai adalah seorang ulama Paderi, yang melakukan aktivitas dakwah meliputi Tapanul Selatan, Tapanuli Utara, Bonjol dan Rao di Sumatera Barat, Dalu-dalu Tambusai di Rokan Hulu propinsi Riau. Bentuk-bentuk dakwah yang dilakukan antara lain, dakwah dalam arti pemurnian (puritanisme) agama, dan Islamisasi serta dakwah dan perjuangan bersenjata melawan Belanda.

Dalam aktivitas dakwahnya Tuanku Tambusai meletakkan perang melawan Belanda sebagai kegiatan dakwah yang harus dilakukan, dan perang yang dilakukannya telah memberikan kontribusi penting dalam kegiatan Islamisasi dan pengembangan Islam di Rokan Hulu dan sekitarnya.
DAFTAR KEPUSTAKAAN

A. Steenbrink, Dr. Karel, Beberapa Aspek Tentang Islam di Indonesia abad ke 19,Bulan Bintang, Jakarta, 1984.

Azra, Prof. Dr. Azyumardi, Jaringan Ulama Timur Tengah dan Kepulauan Nusantara abad XVII dan XVIII, ; Akar pembaharuan Islam di Indonesia, cet.ke 3, Kencana, Jakarta, 2007.

------, Jejak-jejak Jaringan Kaum Muslim; dari Australia Hingga Timur Tengah, Penerbit Hikmah, Jakarta, 2007.

Ahmad Tambusai, Umar, Hikayat Perjuangan Tuanku Tambusai, Badan Pembinaan Kesenian Daerah Riau, Pekanbaru, 1978.

Abdullah, Prof.Dr. Taufiq, (Editor), Sejarah dan Masyarakat; Lintasan Historis Islam di Indonesia, yayasan Obor, Jakarta, 1987.

Al-Azhar, Upah-upah Upacara Tradisi Orang Tambusai, Proyek Pengkajian dan Penelitian Kebudyaan Melayu Depdikbud, RI, Pekanbaru, 1985/1986.

A. Hasjmy, Prof. SEjarah masuk dan Berkembangnya Islam di Indonesia, cet,ke2, PT. Al-Ma'arif, Bandung, 1989.

Ali Aziz, Dr. Moh. Ilmu Dakwah, Kencana, Jakarta, 2004.

Bonnef, Marcel, dkk, Citra Masyarakat Indonesia,Sinar Harapan, Jakarta, 1983.

Dobbin, Christin, Kebangkitan Islam Dalam Ekonomi Petani yang Sedang Berubah; Sumatera Tengah, 1784-1847, terj. Lilian D. Tedjasudhana, INIS, Jakarta, 1992.

Husni Thamrin, (ed), Agama dan Budaya; Transformasi nilai-nilai socialkeagamaan dan sains -teknologi,LPP, UIN Suska Riau, 2009.

Luthfi, Drs. Muchtar, Sejarah Riau, Biro Bina social Setwilda, Tk.1 Riau,Proyek pelestarian dan pengembangan Tradisi Budaya Riau, tahun, 1998/1999.

Nasution, Prof. Dr. Harun, Pembaharuan Dalam Islam; sejarah pemikiran dan gerakan, Bulan Bintang, Jakarta, 1996.

Rahman, Fazlur, Gelombang Perubahan Dalam Islam, PT. Raja Grafindo Persada, Jakarta, 2001. 
J. Moleong, Prof.Dr. Lexy, $M$ etodologi Penelitian Kualitatif, edisi revisi, PT. REmaja Rosda Karya, Jakarta, 2004.

Mukhlis Paeni, (Editor Umum), Sejarah Kebudayaan Indonesia; Religi dan Falsafah, PT.Raja Grafindo Persada, Jakarta, 2009.

Nata, Prof.Dr.Abuddin, Kapita Selekta Pendidikan Islam, Angkas, Bandung, 2003.

Said, H. Mahidin, Adat Dan Kebudayaan Pasir Pengaraian Riau, Badan Pembinaan Kesenian Daerah Riau, Pekanbaru, 1997.

Tamin, Wan Saleh, Lintasan Sejarah Rokan, Badan Pembinaan Kesenian Daerah Riau, Pekanbaru, 1973.

Taufiq Abdullah, (Editor), Sejarah dan Masyarakat; Lintasan Historis Islam di Indonesia, yayasan Obor, Jakarta, 1987.

Tim Redaksi, Album Pahlawan Nasional, PT. Mutiara Sumber Widya, Jakarta, 2004.

Umar, Faisal, dkk, REfleksi Lima Tahun Rokan Hulu, Alaf Riau, Pekanbaru, 2006.

UU. Hamidy, Orang Melayu di Riau, UIR Press, Pekanbaru, 1996.

Wahyu Ilaihi, dkk, Pengantar Sejarah Dakwah, Kencana, Jakarta, 2007. 